Integritas 3.2 (Spring 2014), pp. 1-19.

doi: 10.6017/integritas.v3i2p1

\title{
The Study of Science in Catholic Higher Education in the United States: A Modern Nuisance?
}

\author{
John D. Cunningham, S.J. \\ Loyola University Chicago
}

While the Catholic intellectual tradition can boast of giants in the development of modern physical science, including figures such as Copernicus, Galileo, and a number of Jesuit mathematicians and physicists, still the Church's embrace of science and scientific method has been ambivalent. Catholic higher education has suffered from this historical ambivalence, even while attempting to promote science in the context of a dual commitment to the education of the person and the importance of new research. Today there is a need to think about how to promote scientific education and research in this broader context of the human good.

\section{Introduction}

A frequent debate that occurs among many aspects of American society is the question of whether the study of science is somehow contrary to religious belief. I am frequently surprised how many people are dumbfounded to learn that I am both a Jesuit priest and a particle physicist. The response to discovering this combination of vocations is sometimes the surprising and somewhat comical question, "how can you live with yourself?" Catholic higher education can at times have difficulty trying "to live with itself" in regard to what emphasis the study of science should be given at a particular

John D. Cunningham, S.J., is an associate professor of physics at Loyola University Chicago. His research interests are in the field of experimental particle and astrophysics: cosmic rays, dark energy, and heavy quark particles. He has done research at the Fermi National Accelerator Laboratory and the Argonne National Laboratory. His current physics research involves the simulation and study of various types of supernovae for an upcoming experiment. He is also working on a research project for Loyola's Center for the Catholic Intellectual Heritage on Joseph Bonnecamps, S.J., a French Jesuit mathematician, scientist, and hydrographer who taught at the Jesuit College in Quebec in the eighteenth century. 
institution. In recent Integritas discussions, the challenges of maintaining a "core" set of courses in theology and philosophy, so integral to the Catholic intellectual heritage, have been presented. Almost all of the reductions and modifications of many "core" curricula, especially in regard to theology and philosophy, have resulted from the increasing demands of scientific instruction.

This paper will offer some insight into how Catholic higher education has indeed had some difficulty "living with itself" in regard to the study of science. I will begin by examining the legacy of scientific inquiry in the Catholic intellectual heritage. My emphasis will be on the study of the physical sciences: mathematics, physics, and astronomy. I will next explore the challenges the study of science has presented to many Catholic academic circles. I will then explore the situation of the study of science in Catholic higher education in the United States before World War II, as well as the current situation in the 70 years since World War II. I will conclude with a synthesis of how the challenges in studying science at Catholic institutions in the United States can actually enrich scientific inquiry.

The fact that the study of these philosophical texts

occurred in many Catholic colleges and theological

circles does not make it surprising that the earliest roots

of modern physical science started in the same places.

\section{The Legacy of Scientific Inquiry in the Catholic Intellectual Heritage}

One of the greatest ironies in the history of academic study is the relationship between philosophy, theology, and science. I have chosen to place philosophy and theology together because they were so intimately connected in the sixteenth century when the study of science exploded. Philosophy texts imported from the Middle East were first used to understand many Catholic theological ideas in the thirteenth century. A study of the works of Thomas Aquinas is one stunning example of this phenomenon. The irony is that these same philosophical texts, mostly those of Aristotle's Physics, planted the seeds of inquiry about the nature of terrestrial motion, planetary motion, and cosmology in many for centuries to follow.

The fact that the study of these philosophical texts occurred in many Catholic colleges and theological circles does not make it surprising that the earliest roots of modern physical science started in the same places. The most dramatic example is the life of Nicolas Copernicus (I473-I543) who studied mathematics and astronomy at Jagiellonian University in Krakow. Now labeled as a "revolution" by most, the ideas of Copernicus would transform the techniques of scientific inquiry by using mathematics to calculate and predict physical processes.

Many believe those who studied the stars each night were the original physical 
scientists. It was the order of stellar and planetary motion, assumed to be perfect circles that had many pondering and predicting astronomical events. But the order and perfection of the cosmos had its mysteries. If the earth was the center of the motion, many found planetary retrograde motion baffling. For certain times of the year, Mars would appear to travel backwards in the sky, a phenomenon resulting from Mars being beyond Earth and both objects rotating around the sun. ${ }^{\mathrm{I}}$

By stating that "our star," the sun, was the center of the then-known universe, Copernicus was able to explain the retrograde motion of Mars through mathematical calculations. By making the sun the center of the universe, Copernicus also began the process of de-deifying the natural world, one major source of the nascent conflict between science and religion. What I find most fascinating about those who write about Copernicus is the failure to mention that he was a Catholic priest! While Copernicus implemented mathematics in studying mechanics, the study of motion, and astronomy, it would be a Catholic researcher to the south who would show that experiment is the complementary and necessary aspect of scientific inquiry.

No one personifies the conflict between science and religion more than Galileo Galilei (1564-I642). Stephen W. Hawking, widely regarded as the most brilliant theoretical physicist since Einstein and a man who has made vast contributions in the field of cosmology, writes:

Galileo, perhaps more than any other single person, was responsible for the birth of modern science. His renowned conflict with the Catholic Church was central to his philosophy, for Galileo was one of the first to argue that man could hope to understand how the world works, and moreover, that we could do this by observing the real world.

Galileo had believed Copernican theory (that the planets orbited the sun) since early on, but it was when he found the evidence needed to support the idea that he started to publicly support it. He wrote about Copernicus' theory in Italian (not the usual academic Latin), and soon his views became widely supported outside the universities. This annoyed the Aristotelian professors who united against him seeking to persuade the Catholic Church to ban Copernicanism. ${ }^{2}$

Hawking makes two important points in this passage that need further comment. First, the "philosophy" of Galileo, as he calls it, represents observation. By taking a periscope, improving on and it, and then pointing it toward the night sky, Galileo was able to observe that Venus had phases, much as the moon has phases, as seen from Earth. The only way to explain this observation was that Venus circles the sun as the moon circles the earth. Along with Jesuit astronomers in Rome, Galileo was able to observe the four largest moons of Jupiter, now known as the "Galilean Moons of

1 This observation is much like passing a slower car on the highway which seems to move backwards as you pass it.

2 Stephen Hawking, A Brief History of Time (New York: Bantam Books, 1982), p. 179. 
Jupiter," circling this largest planet. The moons of Jupiter, some nearly the size of the earth, were not circling the sun. As seen from mere observation, it appeared that large celestial objects became the "anchor" for the direction of motion of less massive objects.

Hawking's second point is that Galileo "annoyed” Aristotelian professors, which was truly why so much anger was directed toward Galileo. True to the legend, Galileo was seen tossing objects from the Tower of Pisa and observing their motion. From these studies he made various conclusions in regard to motion contrary to those held by Aristotelians. One such Aristotelian tenet in the Physics was that bodies fall with a speed proportional to their mass. Galileo proved otherwise with some theatrics often thrown in as well. He refused to allow reason to be imprisoned by the "Books of Aristotle," but would look to the "Book of Nature" for insight and knowledge into the physical principles of motion and cosmology.

On the surface, it may appear that much of the anger directed toward Galileo was the result of some bruised academic egos. But the source of this anger was much deeper. Although some point to a handful of accusations against Galileo's statements as being contrary to Scripture, it was his attack on the framework of Aristotelian thought that most disturbed both academic and ecclesiastical circles, both of which were often intimately connected at the time. If one can successfully dismantle Aristotle's understanding of motion and matter, one could equally dismiss such central theological tenets of Catholicism as transubstantiation, built from an Aristotelian framework. Such arguments were being waged by many reformers north of the Alps and were being vehemently rejected in Rome.

In the end, Galileo was convicted of heresy and forced to live his final days under house arrest in the hills outside of Florence. A faithful Catholic until the end of his life, Galileo never found his "philosophy" in any way contrary to his religious belief. Unfortunately the rift between the nascent scientific method and philosophy-theology was formed, a rift that many perceive as quite deep nearly five centuries later.

Although an examination of the conflict between religion and science can be quite difficult, we have seen how the core elements of the conflict were first exposed by studying the works and lives of two Catholic men who were major players in the development of the modern physical sciences: Nicolas Copernicus and Galileo Galilei. By implementing mathematics to explain anomalies in the motion of various astronomical objects, Copernicus's assertion that the sun was the center of the known universe began the first step of many to follow that would subtly remove any influence of the divine in the motion and behavior of the cosmos. Although some found Copernicus's assertion contrary to a handful of scriptural passages, such as in the Book of Joshua where "God stopped the sun from moving across the sky" (Joshua Io:I2-I3), it was Galileo's embrace of the "Book of Nature," understood through observation, that forced the rejection of the "Book of Aristotle," so central to many Catholic theological foundations. This angered many Catholic intellectuals of the period toward science, approaching it with suspicion for centuries to follow. Galileo's new "philosophy" also subtly rejected any outside 
authority in determining what was "true" in the physical world. One cannot deny this reality when observing the rejection of much scientific thought by some popes, Jesuit generals, and cardinals in the centuries that would follow.

\section{The Challenge of Science in Catholic Institutions after Copernicus and Galileo}

Although the ramifications of the Galileo case were severe and absolute, how they were followed was far different in academic circles. One such group to study is the Jesuits at the Roman College in the decades after the Galileo trial. Internal struggles were occurring within the Jesuits over the rejection of Aristotelian thought from the earliest moments of the trial.

Although some were his friends and fellow researchers, many Jesuits at the Roman College turned against Galileo. Some point to Galileo's publication, The Assayer (1623), as the turning point. Written in Italian rather than in the academic Latin of the period, this document rejected submission to authority in the field of philosophy and embraced the rights of research and free intellectual discussion. Although Galileo held true to his vow not to promote Copernican thought directly in The Assayer, he did support the theory very strongly by attacking non-Copernican thinkers, in particular a Jesuit at the Roman College, Orazio Grassi. As Galileo questions in The Assayer, "every idea must be revoked thanks to the recently damned hypothesis [Copernicanism]?"3 Grassi, writing in the pen name of "Sarsi," reacted with equal vehemence and succeeded in uniting most of the Jesuits against Galileo.

Not all of the Jesuits at the Roman College rejected Galileo's "philosophy." One such Jesuit was Giuseppe Biancani ( $\left.\mathrm{I}_{5} 66-\mathrm{I}_{6} 24\right)$ who continued to advocate a more quantitative and descriptive approach to astronomy. Another fascinating piece of Jesuit history is that Galileo's results and discoveries were sent through the Roman College to the Jesuit missionaries in China during the years I6Io and I640.4 If one should visit the lunar exhibit at the Smithsonian Institute in Washington, D.C., today, he or she will encounter the first map used for lunar nomenclature. Drawn in I645 by Francesco Grimaldi, S.J., and published by John Baptist Riccioli, S.J., this map is the first known complete selenography, a graph of the structures of the moon. ${ }^{5}$

The promotion of science in the many decades after Galileo did not occur solely within the Society of Jesus itself. Beginning with Galileo, lay collaborators were always a trademark of Jesuit scientific endeavors. One interesting example is Ohm's Law, which relates the electrical variables of voltage ( $\mathbf{V}$ in units volts), current (I in units of amperes), and resistance ( $\mathbf{R}$ in units of ohms) through the equation: $\mathbf{V}=\mathbf{I} \times \mathbf{R}$. George Ohm taught physics at the Jesuit college in Cologne. André Ampère sponsored the education of the abandoned students of Jesuit schools who, during the "Terror of i830," were dismissed

3 Pietro Redondi, Galileo: Heretic (Princeton: Princeton University Press, 1987), p. 144.

4 Pasquale M. D'Elia, Galileo in China; relations through the Roman College between Galileo and the Jesuit Scientist-Missionaries (1610-1640) (Cambridge: Harvard University, 1960).

5 One fascinating piece of Jesuit trivia is that 35 craters on the moon are named for Jesuits, including one American Jesuit. Sadly, most of them on located on the "dark side" of the moon! 
by the French government when it expelled the Jesuits from France and then confiscated their schools. Alessandro Volta joined the Jesuits for a short time (as did his father!) and then interacted with Jesuit scientists for the rest of his life.

One could continue triumphantly listing many influential Jesuits, their students, and their colleagues in science, but major aspects of modern science were indeed rejected by Jesuit leadership within the order and their educational enterprise. Even before the Galileo trial and most likely in response to growing controversy over Copernican theory, the Fifth General Congregation of the Society of Jesus (I594) stated that Aristotelian doctrine should be followed in all Jesuit teaching. The Father General of the Society of Jesus during the early days of the Galileo controversies, Claudio Acquaviva (I543-I6I5), produced a letter on May 24, I6II, that forcefully stated the need for Jesuits to return to some higher authority, in this case Aristotelian thought, in their academic pursuits. Nearly I50 years later, the Seventeenth General Congregation of the Society of Jesus (I75I) reinforced again that the natural sciences be taught according to the Aristotelian doctrine. This new guideline was in response to the newly emerging Newtonian physics, where forces were now used to explain many of the powers previously attributed to God's influence.

\section{For one to conclude that the study of science died in Catholic academic circles after the Galileo trial is ludicrous.}

For individual science professors in Jesuit colleges, physics would be taught using Aristotle's Physics. But this mandate did not require the study of mathematics to fall under the same restrictive umbrella. For this reason, the biggest contribution to modern physical science made by Jesuits from the sixteenth through eighteenth centuries was through the field of mathematics. These Jesuits include the names of Christopher Clavius (I538-I6I2) and Athanasius Kircher (I602-I680) as well as some students of their schools such as René Descartes (1596-1650).

For one to conclude that the study of science died in Catholic academic circles after the Galileo trial is ludicrous. Although aspects of some scientific instruction were viewed with some suspicion, if not fear, for many decades after, individual contributions to science by many faithful Catholics continued. This was particularly true for the Jesuits who were no minor force in the development of science in the century and a half after the Galileo affair. One historical work highlighting the development of electricity awarded the Jesuit order the honor of being the single most important contributor to experimental physics in the seventeenth century. ${ }^{6}$ Nonetheless, a formal framework

6 William B. Ashworth, Jr., "Catholicism and Early Modern Science," in David C. Lindberg and Ronald L. Numbers, eds., God and Nature: Historical Essays on the Encounter between Christianity and Science (Berkeley and Los Angeles: University of California Press, 1986), p. 154. 
existed within many Jesuit and Catholic institutions of learning that continued to place limits and restrictions on how physical science was to be taught and explored.

\section{The Development of Science in Catholic Institutions before World War II}

In a huge chronological and geographical leap, we examine the situation in regard to the study of science in Catholic higher education in the United States during the nineteenth through mid-twentieth centuries. As with most of this paper, the situation of Jesuit institutions of higher education will be examined primarily, but most of that which occurred in these institutions was paralleled in most all other Catholic colleges and universities in the United States. We will also examine the situation of physical science in the twentieth century. The explosive expansion of knowledge of our physical world at its two extremes: the smallest regions (nuclear and atomic physics) to the farthest regions (stars, galaxies, and supernovae) greatly influenced the attitudes of many toward science during this era.

With the exception of Georgetown University (I789), most Catholic colleges and universities in the United States were founded in the nineteenth and early twentieth centuries. This development both paralleled and benefited from the immigration of various religious orders of men and women, particularly from France, to the United States during this period. Restored by Pope Pius VI in I8I4, the Society of Jesus returned to the United States shortly thereafter.7 Some of their earliest activities were to assume the leadership of a series of Catholic institutions founded by bishops: Saint Louis University (I8I8), Spring Hill College (I830), Xavier (Cincinnati, I83I), and Fordham (I848).

During this same period of the nineteenth century, scientists in mainly England and Europe were studying the topics of electricity and magnetism. A field developed with much mathematical modeling, electromagnetism offered much insight into light and other forms of electromagnetic radiation. But it was the discovery of the electron (I897) by J.J. Thomson in England that would begin another scientific revolution on par with that of Copernicus.

Rather than merely probing the complexities of objects far distant from Earth, physicists began realizing that there existed a whole other "universe" deep within matter at very tiny distances. Suddenly the understanding of the nucleus, protons, and neutrons tightly bound in the inner part of matter, and that of the "electron cloud" surrounding the nucleus, opened a new vision of reality that few could have predicted.

The only Jesuit whose name is mentioned in regard to the explosion of knowledge in the atomic domain is Roger Boscovich (I7II-I789), whom many refer to as the "Father of Particle Physics." 8 A Croatian who taught for 20 years at the Roman College, Boscovich developed the first coherent description of atomic theory in his work, Theoria

72014 marks 200 years since this event: see http://www.sj2014.net/.

8 Once again, most sources fail to mention that Boscovich was a Jesuit and/or Catholic priest. 
Philosophiae Naturalis, where he attempts to explain the universe as a single idea. ${ }^{9}$ His legacy has been preserved in the Bancroft Rare Books Library at the University of California, Berkeley. Persuading Pope Benedict XIV to finally remove Copernicus from the Index of Forbidden Books, Boscovich is also credited with minimizing the continued hostility of Catholic churchmen toward the Copernican theory.

Astronomy was also exploding (literally!) in this time period as well. By the early decades of the twentieth century, the behavior of the farthest reaches of the universe was also opening new possibilities. In the late I920's, Edwin Hubble, who was studying distant Cepheid stars, discovered that they were actually moving outward in space. The universe appeared to be rapidly expanding outward equally in all directions. Once again challenging the static and "perfect" nature of the distant cosmos, Hubble's work forced many questions about the nature of matter in the most distant expanses of space. ${ }^{\text {. }}$

Within this field of study, one Catholic scientist emerged as very prominent in the study of cosmology. Georges Lemaitre (I894-I966), a Belgian Catholic priest, is

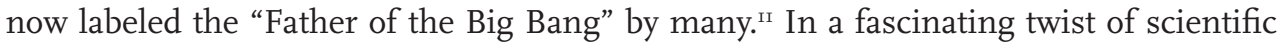
history, Lemaitre had a series of debates with Einstein in regard to the static nature of the universe. Using mathematical analysis and Hubble's experiment results, Lemaitre argued vehemently in support of an expanding universe. Holding a position similar to those in the Middle Ages who espoused the perfection of a static universe, ${ }^{\mathrm{I} 2}$ Einstein "fixed" this apparent anomaly by adding a "cosmological constant," $\Lambda$, into his equations to take into account the expanding universe.

Although many in Catholic academic circles can proudly point to the achievements of Boscovich and Lemaitre for contributing to quantum and cosmological physics, the overall contribution by Catholic intellectuals and their students to this enterprise, as well as almost all other scientific fields, was minimal from the nineteenth through mid-twentieth centuries. This was particularly true in the United States. This reverse in Catholic academic circles from the great scientific achievements of the seventeenth and eighteenth centuries to their near demise by the mid-twentieth century is important to explore. This reverse is all the more important to this paper, because it reflects the stagnation of scientific study in Catholic higher education in the United States in the period before World War II.

By the late nineteenth and early twentieth centuries, the liberal Protestant community and the scholars that belonged to it embraced a new esteem for science and the scientific

9 The Jesuit General of that period, Luigi Centurione, considered Boscovich's teachings as too avant garde.

10 These questions are forefront to physicists today who are trying to understand the nature of dark energy by studying the behavior of distant supernovae.

11 What's ironic about Lemaitre is that he is most frequently labeled as a "Jesuit priest" by many sources; he was a diocesan priest who had once attended a Jesuit high school, the Collège du Sacré-Coeur, in Belgium.

12 God was to be found in the most distant reaches of space. Since God was unchanging, so were the deepest regions of the cosmos. 
method while the Catholic academic community was more entrenched in topics such as scholastic Thomism. The roots of the attitude toward science in the Protestant academic community can be traced back to the aftermath of the Galileo trial and all that was occurring north of the Alps.

A continued study of motion and astronomy in the period after Galileo points to nonCatholics in northern Europe making the most important strides. These would include the astronomers Tycho Brahe (I546-I60I) and his student Johannes Kepler (I57I-I630), who both exposed the non-static and non-circular nature of the cosmos by identifying a supernova and carefully studying planetary motion. The physicist-mathematician of highest fame and influence during this era was Isaac Newton (I642-I747). A devout but unorthodox Anglican, Newton's understanding of gravity through the use of a new branch of mathematics that he invented, differential calculus, cemented both Copernicus's and Galileo's ideas. Newton's notion that forces were the source of motion further removed any sense of the divine as the "Prime Mover" located deep in space, creating all motion on both Earth and the cosmos.

Over time, Newton's conclusions about motion had many Protestant colleges embracing a new "faith" in the scientific method as the best path to truth while not so subtly excluding the divine in any such understanding. And with this began the idea that for one to embrace science one must separate faith from the equation. For this reason, many Protestant-affiliated colleges in the United States began separating theological studies in their colleges, spinning them off to divinity schools and seminaries in the late nineteenth century. The colleges could then devote themselves to creating a curriculum that emphasized scientific objectivity.

One distinctive feature of American higher education is the combination of both undergraduate education and advanced research under one umbrella. A continuing source of tension, this phenomenon first began in the United States with the founding of Johns Hopkins University (1876) as an institution whose primary purpose would be research. Having emphasized scientific objectivity, many Protestant-affiliated American universities readily embraced this combination. Although an anomaly in the network of Catholic colleges of the time, Catholic University (1889) was the first Catholic university in the United States founded as a graduate school.

It should be noted as well that there was a fundamental difference in the intrinsic characteristics of the religious affiliation of Protestant colleges when compared to their American Catholic counterparts. As mentioned earlier, most Catholic colleges in the United States were associated with religious orders, ${ }^{13}$ but their Protestant counterparts were associated with a particular local and lay (less clerically controlled) religious community. When the values and emphases of that lay community changed, so did the associated university. Due to advances in many academic and technological fields, nineteenth century American culture was changing very rapidly.

13 Most of the remaining Catholic colleges were associated with the bishop of a diocese. 
Living as a mainly immigrant subset of the total American society, the Catholic community in the decades before World War II was vastly overshadowed by the Protestant culture of the United States. For this reason, Catholic colleges from the nineteenth through mid-twentieth centuries viewed their mission not as one focused toward objectivity and research but rather as one focused on strengthening Catholic culture and further promoting Catholic identity, an identity primarily centered on the academic subjects of philosophy and theology.

While their secular counterparts were transforming radically in the nineteenth through mid-twentieth centuries, having opted to study the "Book of Nature," Catholic colleges stagnated on many levels while embracing the "Book of Aristotle." Even in the fields of philosophy and theology, Catholic academic circles were far behind their Protestant counterparts during this period. It should be noted as well that the intellectual climate in the Catholic Church during this period was equally stagnant, if not hostile, toward new methods and topics in scholarship. The Oath against Modernism (I9IO) promulgated by Pope Pius X typifies the intellectual climate of this period.

In a previous Integritas essay, David Quigley argues that many graduates of Jesuit universities in the first half of the twentieth century found themselves weighed down by numerous philosophy and theology courses as well as classical language classes, a curriculum reminiscent of a period of preceding centuries. ${ }^{\mathrm{I}}$ This curriculum allowed little room for specialized courses in other emerging fields. For this reason, many graduates of Jesuit institutions were frequently shunned from prominent American graduate schools.

With much anti-intellectual rhetoric flowing from Rome, American Catholic academics and their institutions found themselves under attack from their non-Catholic counterparts, an attack sometimes tinged with some anti-Catholic bias. This was particularly true for the nearly two dozen Jesuit institutions of higher learning in the United States. At one point in the I950's every Jesuit college and university in the United States had a functioning seismograph. ${ }^{15}$ In a letter written in I9०9, these seismographic laboratories were promoted in Jesuit colleges and universities of the United States to offset the attitude by many that the Catholic Church was opposed to modern progress and knowledge. ${ }^{\mathrm{I}}$

14 David Quigley, "The Making of the Modern Core: Some Reflections on the History of the Liberal Arts in Catholic Higher Education in the United States," in Integritas 2.3 (Fall 2013), pp. 1-13.

Due to challenges in technology, among other reasons, many of these have been removed. As recently as December 2013 I received a phone call from a Chicago TV station asking whether the Loyola University Chicago seismograph had recorded an earthquake. (Suburban tremors reported were from a nearby quarry blast.) Inaugurated in 1912, the Loyola Chicago seismograph still functions but now operates by monitoring the motion of an "accelerometer" and is networked into a national earthquake detection website.

16 Agustín Udías, Searching the Heavens and the Earth: The History of Jesuit Observatories (Dordrecht: Kluwer Academic Publishers, 2003), p. 111. 
Although trapped in their own "Catholic ghetto," the Jesuit colleges and universities of the early twentieth century were under suspicion from within the Church as well. In I927, Wlodimir Ledochowski, general superior of the Jesuits, was presented a series of criticisms of American Jesuit collegiate and professional education by the Cardinal Secretary of State. After promulgating some disappointing directives to American Jesuit colleges and universities, ${ }^{17}$ Ledochowski then began a commission (I930) to investigate the state of Jesuit colleges and universities in the United States. The commission was chaired by the Jesuit James B. Macelwane (I883-1956).

A scientist by training, Macelwane studied physics at the University of California, writing a dissertation in seismology. Returning to Saint Louis University in I925, he was the founding director of the department of geophysics and dean of the graduate school (I927-I933). Macelwane became president of the American Geophysical Union and was later elected to the National Academy of Science. From his advanced training in physics at a prominent American university and his experiences of teaching and administration at a large Jesuit university, Macelwane had keen insight into the problems inherent to Jesuit and Catholic higher education at that time.

\section{Although the Catholic intellectual climate of the period was stifling, it was really the historical and cultural context of Catholic institutions in the United States that stymied the study of science.}

Written as an internal document for the Jesuit order, the Macelwane Report was submitted to Rome in 1932. Amazingly, it was ignored for two years by the Jesuit leadership there. But in I934, when the American Council on Education issued a list of 66 approved doctoral programs, Ledochowski and many other Jesuits were shocked to discover that not one of the 34 Jesuit-run programs was on the list. ${ }^{8}$ The document was then very carefully read and understood.

Highly critical of Jesuit institutions at many levels, the Macelwane Report would become a lightning rod for radical change in how Jesuit colleges and universities were operated. From the qualities needed for presidential leadership of the institution to the training of Jesuits for academic positions, the report targeted why the Jesuit institutions were so inferior to their counterpart American institutions. Given the Depression

17 Among these were the exclusion of women from Jesuit institutions and the exclusion of non-Catholics from deanships, chairmanships, and faculty positions.

18 It should be noted that both Catholic University and the University of Notre Dame had doctoral programs that were given the equivalent rating of "honorable mention" by the American Council on Education report. 
and then World War II, these directives would not be seriously instituted until the midtwentieth century.

The nineteenth through mid-twentieth centuries were not a positive time for the study of science in American Catholic universities and colleges. Although the Catholic intellectual climate of the period was stifling, it was really the historical and cultural context of Catholic institutions in the United States that stymied the study of science. Operated by religious orders or clerics, Catholic institutions reflected the intellectual background of these men and women who were frequently improperly trained for the many disciplines they taught and also for the many administrative units they headed. Feeling isolated and "other" by the prominent Protestant culture of this period, Catholic academic circles were reticent to embrace scientific objectivity. The study of science was not seen as part of the Catholic intellectual heritage, as were philosophy and theology, so its study pretty much stagnated. In some core curricula at Catholic institutions, it was completely ignored. By emphasizing the importance of Catholic culture and values over the innovative changes seen in the secular world, Catholic institutions found themselves left behind by the explosion of knowledge in the physical sciences during this era. By the I930's they realized that they had much to do in order to catch up to their American counterparts in higher education.

\section{The Study of Science at Catholic Institutions in the Years After World War II}

By the end of World War II and over a decade since the Macelwane report had been carefully analyzed, many Catholic institutions of higher education raced to improve the study of science. Two factors contributed to this race, the first being that many Catholic institutions had come to realize that they were in a far distant place from the frontrunner American universities in regard to the study of science. The second was a radical change in the student population both in quantity and characteristics. A very large number of men and women returning home after World War II flooded many Catholic institutions. An older and more mature group, flush with much government money, these new students demanded academic programs that would offer them quick employment in an exploding economy. Many of these most popular programs included science and engineering.

This race was very important for the nearly two dozen Jesuit institutions. In I944, Macelwane established the Institute of Technology at Saint Louis University, the university's schools of earth science and engineering. He also became the institute's first dean. Many campuses were quick to construct "cement block boxes" to separate and expand chemistry, biology, mathematics, and physics departments from one central "science" building. ${ }^{19}$

19 The current physics building at Loyola University Chicago, Cudahy Science Hall, was constructed in 1910 to house all science departments in the university. Today physics, chemistry, biology, and mathematics are all separated in large buildings. 
Within the Jesuits, a new program was instituted at Spring Hill College for the training of scholastics, Jesuits in training, who showed interest and promise in science. From the I950's to the I970's this program brought Jesuits from all over the United States to study biology, physics, chemistry, and mathematics while simultaneously pursuing their philosophical studies. This program became a very fertile seedbed for a generation of Jesuits who taught science at various Jesuit universities in the United States. After completing their introductory science and philosophical studies, many of these Jesuits were sent for further graduate studies in science at graduate institutions all over the world.

Many Jesuit institutions also raced to hire well-trained lay science professors to fill in the gaps. One fascinating story is that of Victor Hess (I883-I964), a Nobel Prize laureate in physics, who was at Fordham University from I938 to I958. Hess won the I936 Nobel Prize for his work in discovering cosmic rays, very energetic particles from space that ionize air molecules as they enter the earth's atmosphere. Leaving his native Austria with his Jewish wife, Hess came to the United States to escape Nazi persecution. In the period after World War II, Hess was very instrumental in training a generation of Jesuit and Catholic lay physicists in the rapidly emerging field of experimental particle physics. Many who studied under Hess would later go on to head many of the growing physics departments in Jesuit institutions scattered around the country.

One such Jesuit who studied under Hess was Francis Benedetto (I914-I979), who would eventually become the chair of the physics department at Loyola University New Orleans. Benedetto's eclectic and exhausting path of graduate studies was fairly typical for many Jesuits in the United States who had opted to study science during this period. In Benedetto's memoirs he speaks of wandering north after his introductory courses at Spring Hill College to study under Hess. ${ }^{2 \circ}$ His graduate program involved taking courses at Columbia under Enrico Fermi, another Nobel Prize laureate instrumental with the Manhattan Project; having to travel back to Kansas each fall to continue his Jesuit studies in theology; and then returning to New York each summer to continue his graduate work in physics. ${ }^{2 \mathrm{I}} \mathrm{He}$ also spent some summers working at the University of Chicago where he became intimately aware of nuclear research, later commenting in shock about two nuclear bombs being detonated in Japan.

The emergence of the horrors of nuclear weapons by the mid-twentieth century marked a turning point in the study of science that cannot be ignored. The mysteries of the inner spaces of matter resulted in a weapon of destruction never before witnessed. Humanity had rapidly come to the sobering realization that science could produce catastrophic results. And in this sense, the implications of what science might mean to

20 Henry Garon, A History of Loyola's Physics Department (New Orleans: Central Production Print Shop, 1997), pp. 107-109.

21 While studying philosophy at Fordham University, I wandered into the basement of the McGinley Library to read Benedetto's thesis. In that document, he presents evidence for the existence of the "mesotron," a particle some 200 times more massive than the electron. Today that particle is referred to as a muon. 
the fabric of society produced fear and apprehension far greater than any such feeling during the Galileo affair. This contemporary aspect of science will be discussed further in the conclusion of this paper.

As we examine the study of science at Catholic institutions of higher learning in the early decades of the twenty-first century, the situation is far different than it was a century ago. Many Catholic institutions, as well as the many religious orders that staffed them, must be commended for their incredible leap forward in the study of science in the decades after World War II. The study of science at many Catholic institutions has emerged with strength and is now respected in American higher education. ${ }^{22}$

\section{One might argue that the study of science in}

Catholic higher education is rather a "classical" part of the Catholic intellectual heritage.

But in some sense, it could be argued as well that these efforts were too little and too late. Because the Catholic institutions were so far behind in their development of science programs, they missed out on incredible amounts of research money, mainly from government sources, available in the decades after World War II. Many non-Catholic institutions exploded in their research capacities during this period, thanks in part to this phenomenon. For this reason, it is no surprise that only two Jesuit universities in the United States, Boston College and Georgetown, still have doctoral programs in physics. ${ }^{23}$ And it is nearly impossible at this point in history to imagine a "Catholic Institute of Technology" ever existing in the United States.

\section{Conclusions}

This paper began by asking the question whether the study of science in Catholic higher education was a "modern nuisance." In regard to the word "modern," this paper argued that the earliest roots of the study of modern physical science actually began within Catholic academic circles. In this sense, one might argue that the study of science in Catholic higher education is rather a "classical" part of the Catholic intellectual heritage.

The "nuisance" part of the question is far more complex to address. It is certain that there were documented instances of conflict within Catholic academic circles about the methods and motivations in the study of science. But ultimately the contributing components of each of these questions come down to one central question: can a

22 At Loyola University Chicago, biology is now the largest major in the College of Arts and Sciences. Our undergraduate physics major now has one of the highest enrollments of physics majors for an undergraduate-only program in the United States. Many of the physics graduates of the department enroll in further graduate studies in prominent doctoral programs.

Fordham's doctoral program in physics closed shortly after Hess's retirement in 1958. 
scientific person be a religious one as well? This paper has explored many dimensions of this question.

How is it that Copernicus, a Catholic priest, or Galileo, a devout lay person, or many Jesuits found no conflict in their faith lives while making major contributions to the advancement of science? One answer is that Catholic spirituality embraces a universe where God is intimately present within all aspects of creation. And in that sense, studying creation is to worship God. ${ }^{24}$ One of the favorite pastimes of Ignatius Loyola, the founder of the Society of Jesus, was to climb to the roof of his Roman residence and stare at the stars. During those periods he was frequently moved with great consolation and an even greater desire to serve God. This is concretely recorded in his Spiritual Exercises where in paragraph 235 he states,

This is to reflect how God dwells in creatures: in the elements giving them existence, in the plants giving them life, in the animals conferring upon them sensation, in man bestowing understanding. So He dwells in me and gives me being, life, sensation, intelligence; and makes a temple of me, since I am created in the likeness and image of the Divine Majesty. 25

But what about all the mess after the Galileo affair? A scientist as prominent as Stephen Hawking states that the Catholic Church gave Galileo headaches! The Galileo affair was indeed a very complicated one. One piece of evidence for this is to make a literature search on how many books, many in the last two decades, have been written on this topic. And what about all the evidence from Church documents, particularly those promulgated after the Galileo case, as well as the educational guidelines instituted by the Society of Jesus that supported some suppression of scientific research over the centuries since Galileo?

What is more important in this regard is to understand what the Catholic Church is saying about this situation now. The contemporary stance of the Catholic Church in regard to the relationship between faith and science can be found in the Vatican II document, Gaudium et Spes:

Now many of our contemporaries seem to fear that a closer bond between human activity and religion will work against the independence of men, of societies, or of the sciences.

If by the autonomy of earthly affairs we mean that created things and societies themselves enjoy their own laws and values which must be gradually deciphered, put to use, and regulated by men, then it is entirely right to demand that autonomy. Such is not merely required by modern man, but harmonizes also with the will of the Creator. For by the very circumstance of their having been created, all things are endowed with their own stability, truth, goodness,

24 While visiting the Jesuit observatory on the roof of Castel Gandolfo outside Rome, one will discover some large words painted on the side of the building as one climbs the stairs to the telescope: Venite Adoremus Deum Creatorem (Come let us adore God the Creator).

25 Louis J. Puhl, S.J., The Spiritual Exercises of St. Ignatius (Chicago: Loyola University Press, 1951), p. 102. 
proper laws and order. Man must respect these as he isolates them by the appropriate methods of the individual sciences or arts. Therefore if methodical investigation within every branch of learning is carried out in a genuinely scientific manner and in accord with moral norms, it never truly conflicts with faith, for earthly matters and the concerns of faith derive from the same God. Indeed whoever labors to penetrate the secrets of reality with a humble and steady mind, even though he is unaware of the fact, is nevertheless being led by the hand of God, who holds all things in existence, and gives them their identity. Consequently, we cannot but deplore certain habits of mind, which are sometimes found too among Christians, which do not sufficiently attend to the rightful independence of science and which, from the arguments and controversies they spark, lead many minds to conclude that faith and science are mutually opposed. ${ }^{26}$

In his address to the Pontifical Academy of Sciences on November 10, I979, the centenary celebration of the birthday of Albert Einstein, Pope John Paul II made more explicit references to the Galileo case within the same directives of Gaudium et Spes:

Proceeding from this position of the Council, I urge theologians, scientists, and historians, motivated by a spirit of sincere collaboration, to deepen an examination of the Galileo case, and in loyal recognition of errors, for whatever side they come, put an end to the mistrust to which this affair still gives rise in many minds. This will lead to a fruitful concord between science and faith, between church and world. I give my full support to this task, which can honor the truth of faith and sciences, and open the door to future collaboration. ${ }^{27}$

With both a spirituality that supports inquiry into the created universe as well as a position that seeks to heal the many-centuries-long separation between science and faith, Catholicism has nothing inherent to itself that should exclude or prohibit scientific inquiry. But there is one line in Gaudium et Spes that must be examined carefully: "Therefore, if methodical investigation within every branch of learning is carried out in a genuinely scientific manner and in accord with moral norms, it never truly conflicts with faith." 28

As we stand at the early decades of the twenty-first century, we are only now beginning to assess just what has occurred during the last Ioo or so years. One area of human achievement that exploded as never before in the history of humanity during this period has been scientific discovery and its subsequent spin-off, technology. Most find it difficult to believe that at the turn of the twentieth century we were just beginning to understand that the electron really existed. In the first half of the last century, we

26 Fathers of Vatican II, Gaudium et Spes, paragraph 36, online at http://www.vatican.va/archive/hist_ councils/ii_vatican_council/documents/vat-ii_const_19651207_gaudium-et-spes_en.html.

27 Paul Cardinal Poupard, ed., Galileo Galilei: Toward a Resolution of 350 Years of Debate-1633-1983. (Pittsburgh: Duquesne University Press, 1987), p. xiv.

28 The emphasis on "in accord to moral norms" is purely my own. 
witnessed the revolutionary understanding of the subatomic world become manifest. Sadly too, we saw its results incarnated into nuclear weapons. The second half of that century saw the explosion in the "information age" with the advent of the computer. With sophisticated research in the field of solid state physics, memory chips and processing devices have become faster and cheaper. At the beginning of this century, these trends are only getting more intensified and complicated.

\section{The list of how liberal arts courses can enrich the life of a student studying science can be quite extensive and powerful.}

Scientific research, now fueled by corporate profit, will continue to explode. Although I mention this research as affecting the "inorganic" components of our lives, information, comfort, and transportation, it has been rapidly progressing in the "organic" component as well. These include improvements in health care, the understanding and prevention of diseases, and a resulting increase in human longevities, the psychological and sociological effects of which we are only now beginning to understand. While the twentieth century had to deal with the "inorganic" reality that we were now capable of completely destroying ourselves, the twenty-first century may have to confront the "organic" reality that replicating ourselves is possible as well. ${ }^{29}$

It is in the midst of this shocking reality that Catholic higher education finds itself in a very unique position these early decades of the twenty-first century. The study of science is not a nuisance at Catholic institutions that must be tolerated, nor is it something that must compete and overwhelm the importance of the liberal arts in these institutions. But rather, the study of science at Catholic colleges and universities is vastly enriched by the parallel study of topics in philosophy, where the framework of scientific inquiry can be explored, or in ethics, where the motivations and consequences of scientific research can be discussed and judged,,$^{\circ}$ or in theology, where the spiritual dimension of science can be appreciated, or in various other courses, such as history, where the "wide-angle" view of human activity can be examined and pondered. The list of how liberal arts courses can enrich the life of a student studying science can be quite extensive and powerful.

But as they say about ethical choices, particularly the most profound and challenging ones, the ultimate decision usually converges in the choice between two goods. And

29 Some call the twentieth century the "century of the atom" while the twenty-first century is predicted to be the "century of the cell." Compare Marc Muskavitch's essay in this volume of Integritas (3.1) which addresses the question of genetic determinism.

30 At Loyola University Chicago, one of the core philosophy classes that science majors as well as all students must take includes an ethics course. 
within this reality, Catholic higher education finds itself in the twenty-first century. The curriculum in many fields of scientific endeavor will continue to change and expand in response to further advances in these fields. These changes will continue to place greater and greater pressure on the liberal arts core courses to be removed or further reduced. But this would ultimately be a tragedy for Catholic higher education. The Catholic intellectual heritage embraces scientific inquiry as well as philosophy, theology, and many other liberal arts disciplines. It should have no difficulty "living with itself" over this tension. But how science programs within Catholic colleges and universities can remain respected and viable within this framework in the century ahead may be the ultimate challenge for Catholic higher education in regard to the study of science. 


\section{BIBLIOGRAPHY}

Blackwell, Richard J. Galileo, Bellarmine, and the Bible. Notre Dame: University of Notre Dame Press, I99I.

Clavelin, Maurice. The Natural Philosophy of Galileo: Essays on the Origins and Formation of Classical Mechanics. Cambridge: MIT Press, I974.

Fantoli, Annibale. Galileo, for Copernicanism and for the Church. Translated by George Coyne. Notre Dame, IN: University of Notre Dame Press, I994.

Hawking, Stephen W. A Brief History of Time. New York: Bantam Books, I988.

Lindberg, David C. and Ronald L. Numbers. God and Nature: Historical Essays on the Encounter between Christianity and Science. Berkeley: University of California Press, I986.

MacDonnell, Joseph F. Jesuit Geometers. Saint Louis: The Institute of Jesuit Sources, I989.

MacDonnell, Joseph F. Jesuit Family Album. Fairfield, CT: Clavius Group, I997.

MacIntyre, Alasdair. God, Philosophy, Universities. Lanham, MD: Rowman and Littlefield Publishers, Inc., 2009.

Numbers, Ronald L., ed. Galileo Goes to Jail and Other Myths about Science and Religion. Cambridge: Harvard, 2009.

Redondi, Pietro Raymond Rosenthal, tr. Galileo Heretic. Princeton: Princeton University Press, 1987 .

Sambursky, S. The Physical World of the Greeks. Princeton: Princeton University Press, 1956.

Shea, William M. and Daniel Van Slyke, eds., Trying Times: Essays on Catholic Higher Education in the $20^{\text {th }}$ Century. Atlanta: Scholars Press, I999.

Udías, Agustín. Searching the Heavens and the Earth: The History of Jesuit Observatories. Dordrecht, The Netherlands: Kluwer Academic Publishers, 2003.

Wallace, William A. Galileo and his Sources; the Heritage of the Collegio Romano in Galileo's Science. Princeton: Princeton University Press, I984. 